\title{
Revitalization of Jatidhuwur Jombang Mask Dance as An Effort To Reintroduce Local Cultural Values
}

\author{
Setyo Yanuartuti ${ }^{\bowtie}$, Joko Winarko \\ Department of Arts, Drama, Dance and Music, Faculty Languages and Arts, \\ Universitas Negeri Surabaya, Indonesia
}

Submitted: August 7, 2019. Revised: November 4, 2019. Accepted: December 28, 2019

\begin{abstract}
Millennial era is an era where this generation is generally characterized by increasing the use and familiarity of communication, media and digital technology. This era will bring even further gaps in the attitude of this generation from the values of Indonesian life. The value of this nation's life has long been stored under the arts and culture. In the midst of the downfall of the traditional art life, like the Jatid masked dance, we need the strategy for the young generation to value the local culture for filtering the exposure of foreign culture. This becomes the ground of current Jombang society which directing their art revitalization to the present cultural forms. That becomes the reason behind this study to be conducted. The purpose of this study is to realize the Jatidhuwur mask dance as a medium to introduce Jombang local cultural values to the current generation. The method used for revitalization is dance reconstruction. Reconstruction was carried out with the stages of excavation, setting the structure, developing elements of motion and accompaniment, and packaging, and introducing it to young people in Jombang. Data analysis uses an interactive model in the stages of data collection, data reduction, data presentation and conclusions. The results show that in the Jatidhuwur Mask dance performance there are local cultural values such as religious values, discipline values, life values, and the value of struggle. These local cultural values are revitalized and visualized through art elements such as themes (stories), plot, performance structure, and accompaniment in the touch of new cultivation. The dance is presented in the form of a single dance and a short dance drama (fragmentary), with a touch of technology.
\end{abstract}

Keywords: Revitalization; Jatidhuwur Mask Dance; Local Cultural Values; Millennial Era

How to Cite: Yanuartuti, S., \& Winarko, J. (2019). Revitalization of Jatidhuwur Jombang Mask Dance as An Effort To Reintroduce Local Cultural Values. Harmonia: Journal of Arts Research And Education, 19(2), 111-116.

\section{INTRODUCTION}

Digital technology has dominated human life. Life in the midst of technological development is a fortune in itself. Everything is easy, we no longer need to be difficult to come to the bank just to submit the proof of transfer slip. No need to be hard to find entertainment, just turn on the handphone, open you-tube, just choose what you want to watch.

The digital era is not new at this time, especially for millennial generations. The generation is characterized by the increase of the use and familiarity of communications, media and digital technology. Because it was brought up by technological improvements, millennials have creative,

\footnotetext{
${ }^{\square}$ Corresponding author:

E-mail: setyoyanuartuti@unesa.ac.id
} 
informative, passionate and productive characteristics. Being compared to previous generations, millennials are better friends with technology. This generation is the generation that involves technology in all aspects of life. Real evidence that can be observed is that almost all individuals in the generation choose to use smart phones (Budiati et al., 2018). These conditions cause the presence of a gap between millennial generation attitudes and cultural values of this nation.

National cultural values such as mutual cooperation, andhap asor (polite), mikul dhuwur mendhem jero, and so on are already unknown to millennials. Cultural values stored in traditional performing arts texts will slowly but surely be displaced by advances in technology. Practicality is one of the reasons why the attitudes of human life in this millennial era are far from national cultural values that prioritize togetherness and harmony. How do these millennial children recognize cultural values, if they do not recognize traditional forms of performance art? While traditional performing arts have begun to disappear because no one needs the show, such as the Mask puppet or Jatidhuwur mask dance drama in Jombang.

This dance drama used to be very popular among the people of Jatidhuwur Village and its surroundings. His presence was eagerly awaited because it was needed as a ritual means for healing diseases and promise. The values in the show imply the meaning believed by the community as a role model for community life. Local cultural values such as spiritual values, social values, cultural values, educational values, moral values, the value of asceticism, and aesthetic values contained in the elements of the performance. The Panji story element used in the mask dance drama performance clearly contains a variety of life values of the Javanese people in general and East Java people in particular.

Research Nurhidayah (2017) explained that the Revitalization of Mask Dance was carried out as an alternative media tool in spreading Islamic invitation. The meanings contained in mask dance can explain the reminder to the Almighty, the Creator, the symbols of mask dance explain the moral values that become the content for preaching. For example, about the journey of human life from childhood through adulthood, leadership values, wisdom, love, and even wrath and other noble values. For the community itself, meanings can be used as role models and guidance. Therefore, its symbolic meanings are in harmony with Islamic teachings. In the face of changing times, mask dance also needs to be developed in accordance with the demands of the development of modern technology today. Although there is a cultural inheritance from generation to generation, there is no guarantee that local culture will remain firmly nurtured to face the challenges of globalization which offer an increasingly pragmatic and consumptive lifestyle.

When the Jatidhuwur Mask art collapsed because it was rarely performed, the revitalization approached by the characteristics of the millennial generation became very necessary. In the midst of the development of this technology, to maintain and preserve the life of traditional arts such as the Jatiduwur Jombang mask dance drama, it needs attention and a creative touch of technology. Art creativity is one of the most important methods to be carried out so that people, especially the younger generation, now enjoy and involve in building their lives. The revitalization of performances that can be done in building and reviving this art is to do technologicalbased artistic creativity.

\section{METHOD}

This research uses a qualitative approach. A qualitative approach is defined as a research procedure that produces descriptive data in the form of written or oral words from people and the behaviour observed. According to Moleong (2002) qualitative research is often used to examine phenomena in natural social and cultural life. 
The approach used in this research is the revitalization of art with the dance reconstruction method. Reconstruction was carried out with the stages of excavation, setting the structure, developing elements of motion and accompaniment, and packaging, and introducing it to young people in Jombang.

\section{RESULTS AND DISCUSSION}

\section{Revitalizing Jatidhuwur Jombang Mask Dance Drama}

Revitalization is the concept of preserving art with a form of development to regenerate arts that are becoming extinct. Revitalizing art is done by developing traditional art in vital parts with a modern touch. Revitalizing art is still vital in reference to traditional art as its main reference, so that the process can be done by mutrani (nunggak semi), which is imitating a standard but processing techniques and materials in accordance with current needs (Kartika, 2016).

Revitalization of traditional art is very necessary because it can revive the art so that it has a presence in society and can encourage artists to be loyal to the arts. This is as expressed by Endang Wara that:

Revitalizing the position of traditional art in society so that it can be the local pride. Some of the local people are cynical and consider the traditional art boring, uninteresting, and out of date. The revitalization is needed because it can revive and encourage the artist to be loyal to art. Helping the conservation effort of traditional art because it is loved by the people and is considered as their identity (Suprihatin Dyah Pratamawati, 2015).

According to Sudarso (1998), revitalization can be done in two ways, namely textual and contextual.

Textual revitalization is revitalization carried out in a particular branch of art either by restructuring an branch of art being worked on, by combining other texts of similar or different types, or by improving the function of existing texts (Sudarso, 1998).

Meanwhile contextual revitalization is done more to be used for other interests outside the art itself. Contextual revitalization is revitalization carried out by combining text with other texts originating from the outside, or utilizing a text for other purposes or functions outside the art itself (Sudarso, 1998).

Jatidhuwur Puppet Mask is a masked dance performance which is arranged by a puppeteer. The dancer moves his body as a form of visualization of the puppeteer's speech (monologue or dialogue) in accordance with the story that he is carrying. The motion character that is realized in accordance with the character of the mask character.

The revitalization of the Jatidhuwur mask dance drama has been started since 2000 until now. Supriyo is one of the figures in Jombang who played a role as a pioneer in the revitalization of mask puppets that had previously been suspended. Revitalization is done textually by restructuring the story as it is. The developed art text is fashion because in the past the mask dance performance only used clothing that paid less attention to the performer's characters. For example, a dancer wears a t-shirt or shirt that at that time is used, which is added by the use of a long cloth. The performer's characters are only manifested through masks, headwear (jamang), and praba. The form of clothing developed at that time was that male figures did not wear top or ngligo (topless), and add fashion ornaments such as rapek and kace necklaces. The condition of the Jadidhuwur mask performance form like that lasted until 2012. Meanwhile in 2013-2014, the mask drama performance experienced a vacuum due to internal problems (Yanuartuti, 2015).

The revitalization of Jatidhuwur mask dance drama was continued by Unesa's research team starting in 2015 with the stages of excavation, reinforcement of vital elements, development based on vital elements that have strength values such as development of motion characteristics, dance development based on unique characters, development of story structures, development of the performan- 
ce forms through an artistic approach, and development of the concept of working on a performance with a contemporary touch. The approaches used in this revitalization include restructuring, reconstruction, reinterpretation and transformation (Yanuartuti, 2016).

\section{Revitalization as a media to recognize lo-} cal cultural values for young generation

Revitalization as a media to recognize local cultural values for the younger generation Today's young generation is very different in character from the past generation. Technology greatly influences the culture of thinking, culture of behaviour and attitude in their daily lives. The generation also known as generation $\mathrm{Y}$ or millennial more idolizes figures from foreign artists, who then become a reference in lifestyle. The lifestyle of this generation refers to the style of characters that often appear on internet or you-tube sites through the smartphone that he always carries. As stated by Ali Said et al (Budiati et al., 2018) by referring to a Boston Consulting Group (BCG) study with the University of Berkley in 2011 in the United States that millennial generation has the following characteristics:

Interest in reading conventionally has now declined because Generation $Y$ prefers to read through their smartphones; Millennials must have a social media account as a communication tool and information center; Millennials definitely prefer smartphones to television. Watching a television program is no longer an entertainment because they can find anything on a smartphone; Millennials make the family a center of consideration and their decision makers (Budiati et al., 2018)

The millennial period will also bring even further gaps in the attitude of this generation from the values of Indonesian life. If this is allowed, generation $\mathrm{Y}$ does not recognize the values of local wisdom that can be used as role models in the life of the nation and state.

Revitalizing traditional dances such as the Jatidhuwur Jombang mask dance is also intended to be able to reintroduce the values of local wisdom. The values that can be built and introduced to the generation $Y$ are values of passion, values of service, values of struggle, values of asceticism, and values of friendship.

The values of spirit are built through the process of revitalizing the Gladhen dance, Mbanmban dance, MaduretnoCitrolangenan dance, and the Patah $\mathrm{Ku}$ danarawangsa dance drama. The value of passion is the value of life that we must always hold. Because living with a sense of enthusiasm makes us people never give up, always rise when being slumped, and the spirit to keep fighting.

In the Gladhen dance, the value of spirit is in the motion text. Gladhen dance is a mask dance revitalized from the patterns of war movement in the Jatidhuwur Mask Puppet. This dance depicts warriors who are practicing war. This character of the warrior's training spirit is revitalized in the Gladhen dance in the hope of introducing that value to young generation today in Jombang. Children who join in the Jatidhuwur Puppet Mask group began to recognize the value of spirit when dancing this dance.

Mbanmban mask dance is a revitalized dance with a source of inspiration from the Emban figure in the Jatidhuwur Puppet Mask. This Emban figure is a royal servant figure of the king of Gumbalaraja from the Simbar Manyura kingdom. The value of local wisdom built through Mbanmban dance is the value of passion and devotion. An Emban is a figure whose life as a whole is devoted to his boss or king. This value is actualized through characters and motion text arranged in comical types so that it becomes interesting for the current generation.

The short dance drama or fragmentary of Maduretno-Citrolangenan is a mask dance revitalized from the continuation of Patah Kudanarawangsa's story. This dance tells the story of the struggle of Dewi Sekartaji and Panji Inukertapati to rediscover their unity and also eliminate evil. The disguise of the name Maduretno for Panji, 
and Citrolangenan for Dewi Sekartaji is a form of struggle to achieve the hope of unity of life. Through revitalization, this dance can introduce the values of the struggle which is not easy to give up. In addition to the value of this fragmentary struggle, it also introduces the value of enthusiasm and asceticism. The value of asceticism is manifested through the Maduretno scene when meditating in the forest to unite the mind and heart to beg and submit to God in connection with the predestined relationship with Panji.

The Patah Kudanarawangsa role is one of the Panji plays in addition to the Serat Kudanarawangsa by Moelyono, et al $(19$...) also used in the Jatidhuwur Puppet Mask before performing revitalization (Yanuartuti, 2015). The play was revitalized twice in 2012 and 2017 in the form of a mask dance drama. In 2012, this play was performed at the Mpu Tantular Museum, with a structure in accordance with the old structure. In 2017 the play was revitalized again with an approach to the transformation of forms and values. Shape transformation is done by building structures with simpler stresses but emphasizing dynamics. Value transformation is done to change the value of love or romance into the value of friendship. This was done to bring the value for the players who were elementary school children at the time. The introduction of the value of friendship is transformed from the love value of Panji Inukertapati with fake and genuine Dewi Sekartaji. The transformation of the value of friendship is very important to build the character of children, especially those who involved in the revitalization process, and is also expected to be able to introduce that value to children and young people in general. This drama also introduces the values of enthusiasm, struggle and asceticism. The values of enthusiasm and struggle are visualized through the story of Dewi Sekartaji when excited and struggling to make friends again with Panji Inukertopati, which is carried out through his disguise becoming Patah Kudanarawangsa.

The dance drama performance of $\mathrm{Pa}$ - tah Kudanarawangsa is packaged with a touch of technology, and artistry through elements of stage engineering and lighting techniques. With a touch of this techno$\operatorname{logy}$, it is produced new artistic value in the performance of the Jatidhuwur mask dance drama. The increase in the quality of the show is an attraction for children and young people. The results of the show are then packaged into social media packaging, which is YouTube, which can be consumed not only by Jombang generations and people but also by people everywhere.

The revitalization approach to mask dance that has been carried out has been packaged in the form of VCD, DVD, MP4, and also YouTube. This form of mask dance packaging will be able to help introduce the cultural values of the Indonesian people to millennial generation, with the hope of helping to strengthen the character in filtering the flow of foreign culture that can not be dammed anymore.

\section{CONCLUSION}

The gap that occurs between the attitude of millennial generation and the value of the life of the Indonesian people cannot be ignored, but it should be responded to and sought a solution. The values of local wisdom which are a form of cultural values are stored in many joints of traditional performing arts texts such as mask puppet. Revitalizing mask dance is one alternative to be able to introduce national cultural values stored in the Jatidhuwur Jombang mask puppet. The approach that can be taken in rebuilding cultural values is to bring the forms of art presentation closer to the characteristics of millennial generation. Making the mask dance presentation packaging with a touch of technology, which is then repackaged as a result of the show in the form of DVDs, MP3s, MP4s, you-tubes that can be distributed through social media is a strategy so that the values of the performances of the mask dance drama are known and can build millennial generation characters. 


\section{ACKNOWLEDGMENTS}

The research was completed because of the help of various parties. The writer thanks Mbah Sumarni (heir of the Jatidhuwur mask), Pak Supriyo (deceased, pioneer of Mask Puppet revitalization), Moch Hariono (who faithfully assisted during the introduction process until the revitalization of the Jatidhuwur mask).

\section{REFERENCES}

Budiati, I., Susianto, Y., Adi, W. P., Ayuni, S., Reagan, H. A., Larasaty, P., Setiyawati, N., Pratiwi, A. I., \& Saputri, V. G. (2018). Profil Generasi Milenial Indonesia (A. Said, I. Budiati, R. B. R. Rahayu, \& A. P. Raharjo (eds.)).

Kartika, D. S. (2016). Kreasi Artistik (Perjumpaan Tradisi Modern dalam Paradigma Kekaryaan Seni). Karanganyar: LPKBN Citra Sain.

Moleong, L. J. (2002). Metode Penelitian Kualitatif. Jakarta: Remaja Rosda- karya.

Nurhidayah, Y. (2017). Revitalisasi Kesenian Tari Topeng sebagai Media Dakwah. Ilmu Dakwah: Academic Journal for Homiletic Studies. 11(1), 21-52.

Pratamawati, E. W. S. D. (2016). Malang Mask Puppet Presentation Structure Arrangement of the Story Rabine Panji as Cultural Tourism Commodity in Malang Regency East Java. Harmonia: Journal of Arts Research and Education, 16(1), 66-74.

Sudarso. (1998). "Seni dan Keindahan". (Dalam Pidato Ilmiah. Pengukuhan Guru Besar Tetap Fakultas Seni Rupa ISI Yogyakarta.

Yanuartuti, S. (2015). Revitalisasi Wayang Topeng Jatidhuwur Jombang Lakon Patah Kudanarawangsa. Surakarta: ISI Surakarta.

Yanuartuti, S. (2016). Building Creative Art Product in Jombang Regency by Conserving Mask Puppet. Harmonia: Journal of Arts Research and Education, 16(1), 30-37. 